\title{
Waqay: a word about water and the Andean world in a twentieth-century Spanish manuscript from Huarochirí (Peru)
}

Sarah Bennison

\begin{tabular}{|l|l|}
\hline Date of deposit & 01 October 2021 \\
\hline Document version & Author's accepted manuscript \\
\hline Access rights & $\begin{array}{l}\text { Copyright C } 2021 \text { Trustees of Indiana University. This work is } \\
\text { made available online in accordance with the publisher's policies. } \\
\text { This is the author created, accepted version manuscript following } \\
\text { peer review and may differ slightly from the final published } \\
\text { version. }\end{array}$ \\
\hline $\begin{array}{l}\text { Citation for } \\
\text { published version }\end{array}$ & $\begin{array}{l}\text { Bennison, S. (2021). Waqay: a word about water and the Andean } \\
\text { world in a twentieth-century Spanish manuscript from Huarochirí } \\
\text { (Peru). Anthropological Linguistics, 61(4), 459-490. }\end{array}$ \\
\hline $\begin{array}{l}\text { Link to published } \\
\text { version }\end{array}$ & \begin{tabular}{l} 
https://www.muse.jhu.edu/article/803828 \\
\hline
\end{tabular}
\end{tabular}

Full metadata for this item is available in St Andrews Research Repository at: https://research-repository.st-andrews.ac.uk/

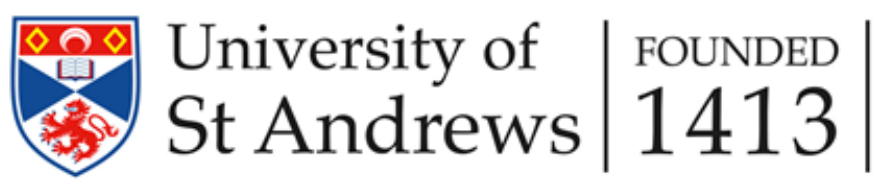




\title{
'Waqay': A Word about Water and the Andean World in The Entablo, Spanish Manuscript of Huarochirí (Peru)
}

\author{
Sarah Bennison \\ University of St Andrews
}

\begin{abstract}
This paper is one of the first scholarly studies to draw on The Entablo, an important and newly-accessed early twentieth century manuscript from the highland Lima village of San Pedro de Casta. The paper explores the linguistic landscape within which the text - an internal set of irrigation ritual regulations based on Inca precepts - emerged, then offering a highly contextualised analysis of the Quechua word 'waqay', which features in this predominantly Spanish language text. The term in question merits thorough analysis and contextualisation, being central to Andean conceptualisations of landscape, spirituality, and communication. In the local context, agro-pastoral production and community wellbeing hinge on the deliverance of the word 'waqay' in the annual canal-cleaning ritual, performed each October. ${ }^{\mathrm{i}}$
\end{abstract}

The change-inducing effects of early twentieth century nation building on language are perhaps nowhere as stark as in the highland Lima province of Huarochirí, famed for its early colonial Quechua manuscript and today taken to be Spanish speaking by local people and scholars. Here, just as in the Andean regions acknowledged to be Quechua and Aymara speaking, people must maintain and negotiate relationships with non-humans in order to secure their existential and economic wellbeing. 
In the recent history of ontologically-inclined anthropology, studies of the Peruvian Andes have focused largely on the relationships between humans and non-humans in Quechua-speaking communities, creating a misleading impression that self-defining Spanish speaking communities pose an ethnographic exemption. Beyond the realm of academia, the conflation of indigenous identity with the speaking of an indigenous language in Peruvian politics likewise leaves self-defining Spanish speaking Andeans in an underrepresented-and furthermore vulnerable - position. At the time of writing, no communities from Huarochirí are listed on the Database of Indigenous and Originary Peoples (Base de datos de Pueblos Indígenas u Originarios) in Peru. ${ }^{\text {ii }}$ Developed following the approval of Prior Consultation Law for indigenous groups in Peru in 2011, the database currently includes fifty-five indigenous groups, categorised according to the respective indigenous languages spoken by these groups. The groups which feature have the right to be consulted in the event of development projects proposed to take place on their ancestral lands. In this respect, language status is an important factor in securing access to land rights in Peru. The conflation between language and identity in such legislative contexts has, thus far, has gone unchallenged in the Andeanist anthropological literature.

In this paper, I will explore the language-identity nexus through exploring ways of speaking in Huarochirí. To do so, I will present a case study which problematises the readiness with which anthropologists and policymakers align and assign identities (indigenous or otherwise) with individually categorised languages. The paper calls these essentialising approaches into question, yet it does not theoretically resolve them in any simple way either. In the words of Nuckolls, "Language and culture are neither in lockstep with each other nor totally independent of one another" (Nuckolls 2010:3). If we are to apply this premise in policies relating to indigenous peoples and languages, how might we account for contexts where clear-cut language identities are irrelevant? How might we account for communities such as those in 
Huarochirí where indigenous language words feature prominently in ancestral domains such as water rituals?

In line with ritual regulations set out in a community manuscript called The Entablo in 1921, the Quechua word waqay should be shouted out loudly today during the annual irrigation ritual in the Huarochirí village of San Pedro de Casta in order to facilitate communication with a water-owning landscape being ${ }^{\mathrm{iii}}$.

In focusing on the role of this word, I will seek to explore the association between words and worlds through a consideration of the ontological outlook that locals express when they choose this word (over a Spanish word) when communicating with the local landscape beings. Is the persistence in Huarochirí of indigenous language words in community-huaca interactions indicative of an (extant) 'Quechua ontology' (Mannheim and Salas Carreño 2015:47)? Mannheim and Salas Carreño write: "Bound up in any discussion of wak'a is the nature of social agency and the ways in which it is embedded in a specifically Quechua ontology—-that is, specifically Quechua ideas of the kinds of objects that exist in the world and their interaction with each other" (Mannheim and Salas Carreño 2015:48). Is this framework applicable, or does the case of Huarochirí as a province with Quechua language persistence yet often presented as exclusively Spanish speaking caution us to decouple language and ontological outlook?

Course (2018:12) has described the ways in which language, through the act of speaking, is understood to have a force among his bilingual Mapuche interlocutors, where Spanish, the language of the Chilean state and of modernity, is ontologically divergent from Mapudungun, which is associated with the land itself and is the preferred language for rituals. This ontological distinction holds true for Huarochirí: indigenous language words communicate the force of the land, and they are used by humans in rituals to charge the land with force at the end of the dry season so that its materiality spills over, bursting out as rain. In this respect, the findings from 
Huarochirí hypothetically support a 'Quechua ontology'. Nevertheless, paying serious attention to the absence of formal linguistic categorisation by speakers in Huarochirí necessitates an eschewing of language categorisation and of the language-based indexing of identities. If Huarochirí speakers do not acknowledge some of the words they speak to be indigenous language words, then it would be unethical and theoretically unrepresentative to make a case for the relevance of a 'Quechua ontology' in Huarochirí today, since to do so would override local understandings of ways of speaking, silencing non-Western ontologies of communication where the preoccupation with naming languages serves no constructive purpose. If languages can be powerful and carry their own force in the way described by the Mapuche (Course 2018:21), then we should not underestimate the (quite distinct) force of the Spanish language beyond and within the ritual domain.

The recent ethnographic record shows that in highland Peruvian communities which have undergone language transformation from indigenous languages to Spanish, words, phrases, and songs are today voiced in indigenous languages within the domain of agro-pastoral rituals (Bennison 2016, Salomon 2002, Rivera Andía 2005:62). ${ }^{\text {iv }}$ Mannheim's research has illustrated that the differing functions of Quechua and Spanish in bilingual areas of Cuzco are reflected in the languages that speakers draw on: Pachamama and other landscape beings are addressed in Quechua, whereas State manifestations of power are addressed in Spanish (Mannheim 1991:81). Bilingualism does not seem to have altered the compatibility of the respective languages with these two ontologically distinct domains. As I shall explain, it is likely that a similar linguistic pattern emerged in Huarochirí, although the speaking of indigenous languages during rituals appears to have decreased in the province over the last century. During a fieldtrip to Casta in 2019, I was sung a short agricultural song primarily in Quechua, suggesting that indigenous language persistence may be observed today in traditions acknowledging the productive power of the landscape. During the same trip, I was advised that 
communication with landscape beings requires a vocabulary inclusive of 'strong words' such as swear words, in the event that a landscape being should seek to interact with you with malicious intentions. A ritual petition for rain would require a slightly different vocabulary, though the word used to penetrate the realm of the landscape beings in Casta is similarly 'strong'.

During fieldwork in Casta in 2019, I was told that today, the word waqay should be cried out loud during ancestral irrigation rituals. Given that this practice was instructed in The Entablo a century ago, we can appreciate that the highly localized communicative context of water ritual prevents the silencing of Quechua, where it echoes resoundingly for all to hear. The inclusion of this word in The Entablo, the official set of ritual guidelines for the canal cleaning ritual, underscores its centrality to the ritual proceedings. In this respect, The Entablo dictates a necessity for the continued use of this key word in a context of linguistic and, relatedly, broader processes of social change in the early twentieth century. Much of the late twentieth and early twentieth century literature on Huarochirí has highlighted the persistence of ancestral customs in various Huarochirí communities in recent decades, many resembling those described in a well-known early colonial Quechua account of 'Indian' customs from the province, the socalled Huarochirí Manuscript of 1608 (Gelles 1984, Ortiz Rescaniere 1980, Llanos and Osterling 1982, Salomon 1998, Salomon 2004). The ritual instructions in the 1921 Entablo manuscript likewise evidence the persistence of pre-Hispanic customs resembling those described in the Huarochirí Manuscript of 1608. As I shall suggest, the Entablo regulations oblige us to acknowledge the central role of ritual legal texts and associated pre-Hispanic Andean inscriptive traditions for promoting persistence and discouraging innovations to landscape-focussed ritual discourse, including language use, over the last four centuries.

This paper seeks to explore the language-ontology nexus through an analysis of The Entablo manuscript, which was written largely in Spanish, and recent fieldwork data exploring the 
continued relevance of this text today. The paper argues for greater attention to indigenous language persistence in Huarochirí villages and to the ontological incommensurability of Quechua and Spanish in contexts of presumed indigenous language loss over the last century. The linguistic intricacies of human-non-human ritual relationships in Huarochirí are a difficult topic to explore, given the sensitivity of discussing 'old words' in a province whose inhabitants tend to describe themselves as exclusively Spanish-speaking. The lasting effects of centuries of discrimination against Andean people and their ways of life should not be underestimatedparticularly for this province, whose pre-Hispanic customs were recorded in Quechua for colonising purposes. An analysis of The Entablo will illuminate the indispensability of indigenous language words through, and despite, the last century of language transformation.

\section{The Entablo and the Water Laws of Casta}

The Entablo represents an important new source for the study of Andean society. Written in San Pedro de Casta (Huarochirí province, Lima) between 1921 and 1952 as a collective endeavour by community authorities in office at the respective time(s) of writing, the text sets out the village's agreed guidelines on proper ritual discourse. ${ }^{v}$ Spanning sixty-two pages of principally Spanish language content, most of the instructions relate to the well-documented canal-cleaning ritual (champería or fiesta del agua) which takes place throughout the first week of October towards the end of the long dry season (Gelles 1984, Llanos and Osterling 1982, Ráez Retamozo 1995, Tello and Miranda 1923). The champería in Casta is performed in honour of the landscape being Wallallo (Tello and Miranda 1923).

The Entablo also contains a brief addendum advising on proper ritual discourse for the rainy season traditions, including New Year and Carnival (in January and February, respectively). The manuscript, which is today guarded under lock and key by the authorities of the Peasant Community of San Pedro de Casta, specifies and demarcates the duties and obligations of 
each of the ritual authorities ('funcionarios' or 'functionaries') of the village's key economic and social event on a day-by-day basis. ${ }^{\text {vi }}$ The manuscript is used today to train ritual initiates and is described by those familiar with its content (i.e. current and former functionaries) as a bible. When I asked a village elder, Eufronio Obispo Rojas, what he took the word 'entablo' to mean, he defined the word as "a code of conduct or a law." express their hopes to have ritual discourse correspond, as much as possible, with the "many laws of the incaic era" (CCSPC 1921:f.19) ${ }^{\text {viii }}$ In the description of the text as both a bible and 'a law', it is helpful to think of The Entablo as a sacred and authoritative scripture, and to consider its preceptive content in a constitutional light.

As a key economic, religious, political, and legal document, The Entablo was written by, and in consultation with, village elders, drawing on centuries of ancestral (largely pre-colonial) irrigation knowledge. In 2019, the aforementioned elder Eufronio Obispo Rojas explained to me that The Entablo came into existence in the absence of older inscriptive devices such as khipu accounts and, latterly, hybrid khipu-text board accounts (padrones). ${ }^{\text {ix }}$ Tello published a drawing of a khipu board padrón he observed being used in Casta during the champería in 1922 (Tello and Miranda 1923). 


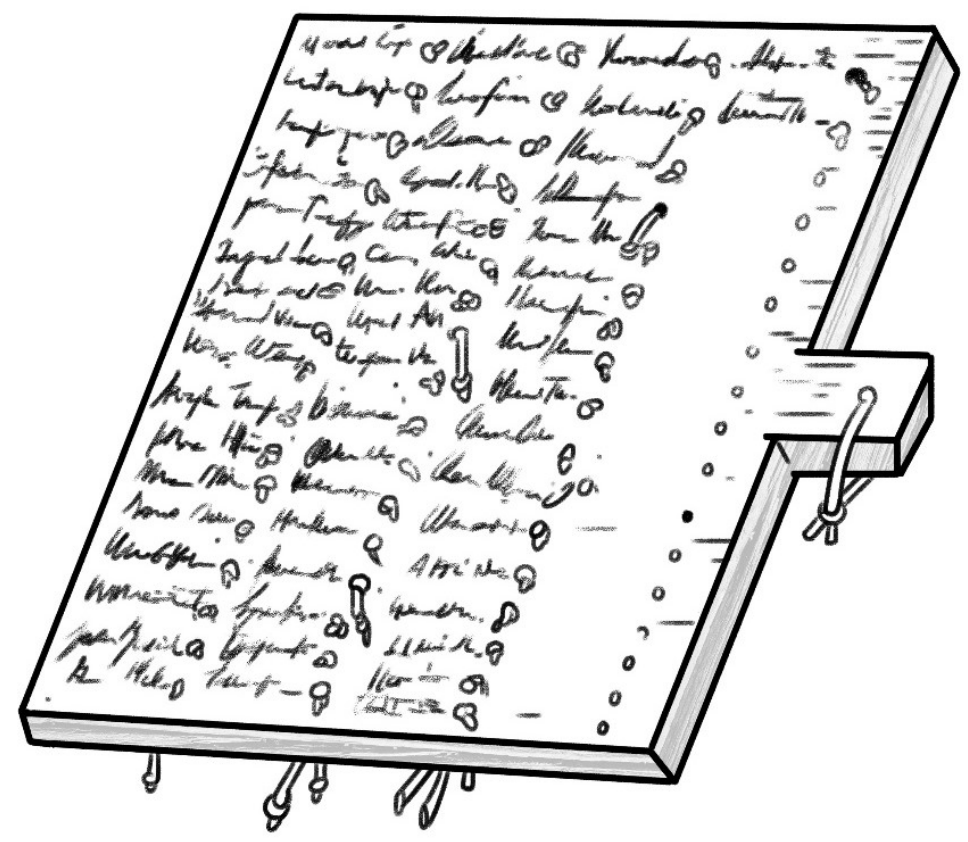

Figure 1. Tello's drawing of a khipu board from Casta. (Redrawn by Eleanor Hyland).

Khipus are knotted fibre inscriptive devices of pre-Hispanic origin which were used to record ritual obligations and individual contributions in labor and in kind (Hyland 2016). According to Eufronio, these precepts had fallen into disuse or become lost and a new record setting out the necessary ritual provisions and discourse was needed. ${ }^{\mathrm{x}}$ At the beginning of The Entablo, its contributors clarified the motivation behind their project in a section entitled and dedicated to 'Los ciudadanos de Casta' ('The citizens of Casta'). ${ }^{\mathrm{xi}}$

En vista de muchos controles y desacuerdos en las obligaciones comensando desde el teniente asta el último que es el camachico no cumplen con sus obligaciones y deberes acordaron hacer constar popularmente bajo nuestras firmas afin de hacer cumplir y cumplan puntualmente y no aleguen motivo titulandose de no haber constancia y menos fuerza de ley. ${ }^{\text {xii }}$

[CCSPC, 1921 f.3] 
In light of the many interventions and disagreements concerning the obligations [of ritual functionaries] starting from the Teniente [Lieutenant] right down to the last functionary, which is the Camachico, ${ }^{\text {xii }}$ the functionaries are not fulfilling their duties and obligations. They agreed to collectively set down an official record, under [the jurisdiction of] our signatures so that they are obliged to fulfil their duties and so that they fulfil them in a punctual manner and cannot give the excuse of taking on their roles without there being a written record and making claims to diminished force of law. [CCSPC, $1921 \mathrm{f} .3]$

If all functionaries could fulfil their duties sufficiently, the ritual would go well and water would flow through the canals to the fields, should the sacred ancestors allow. In the above extract, we can appreciate the importance of having a written point of reference, which would be collectively agreed upon. In the same section of the text, the contributors explained why conducting the champeria correctly was of utmost importance:

Como todos nos sometimos a este regim por ser la base fundamental por el caño de donde vivimos y saciamos nuestra sed desde que nace hasta que llegua la última hora de nuestra muerte nos sometimos a firmar en el presente libro a fin que quede constancia para los futuros los dictamines dictadas por la comunidad y tres ancianos notables que al fin se hallara grabado sus nombres. [The Entablo, 1921 f.3] 
Since we all submit ourselves to this legal-political regime, because it is the fundamental basis, because it is the water and life source of where we live and quench our thirst from birth until the final moment of our death arrives, we hereby submit ourselves to the task of signing in this book so that an official record exists for the future [years through] the expert knowledge and judgment dictated by the community and three notable elders who, at the end, will have had their names recorded. [The Entablo, 1921 f.3]

Thus, the beginning of The Entablo makes it clear that a preoccupation with future water availability was a driving force behind this project. An earlier sacred text from the neighbouring village of San Damián, the Quechua language Huarochirí Manuscript of c.1608, describes (in chapter twenty-two) how in times of drought, members of the Checa kin group or ayllu would make offerings of gold and silver to a sacred mountain known as Sucya Villca, and that, relatedly, the Inca would keep a special khipu account of the exact details of offerings which should be made to every single landscape being (huaca) without fail (Salomon and Urioste eds. 1991:112). Thus, access to water was negotiated with huacas, and ritual account-keeping was a central aspect of monitoring and quantifying these interactions. Based on his analysis of the huacas featuring in the Huarochirí manuscript, Salomon describes a huaca as "any material thing that manifested the superhuman: a mountain peak, a spring, a union of streams, a rock outcrop, an ancient ruin, a twinned cob of maize, a tree split by lightning. Even people could be huacas" (Salomon 1991:17). In Huarochirí villages today, sacred rocks, Pre-Hispanic ruins, and sacred objects are key agents in securing the water needed for agro-pastoral production.

We can therefore appreciate that inscriptive devices such as khipus, khipu boards, and analogous community documents such as The Entablo have been central in facilitating 
communication with huacas in Huarochirí since at least the Inca period (emerging c. 1400 CE), if not before, during the Wari empire (600-1000 CE) (Urton 2017:5-37). The persistence of these records in a general sense (however they evolved) indicates a lasting adherence to an understanding that irrigation water is a product of effective ritual communication between landscape beings and humans. To be on good terms with a huaca, it was crucial to understand and remember their specific wants and needs. And to do this, it was necessary to be able to communicate with them to secure their continued attention and guardianship.

This paper will demonstrate the essential nature of employing indigenous language lexica in the context of localized ancestral ritual and ritual texts, where Spanish-a language which developed outside of the Andes - cannot fully communicate the nature of the proceedings and pacts set down as village law in order to preserve Inca era morals and customs. The way in which language has developed in Huarochirí suggests that we should reconsider the relevance of terms such as 'Quechua ontology', which do not easily map onto contexts such as the one explored here. Conversely, we could ask: if a community has stopped speaking Quechua, but draws on Quechua lexicon in ritual contexts in order to bring on rains, then does this suggest that further consideration of the association between language and ontological outlook is needed?

\section{Inca Cosmopolitics and Quechua Ritual Dialogue in Huarochirí}

One of the ways in which locals in Casta—both a century ago and today—have orally interacted with the water-owning landscape beings (i.e. huacas) has been through their speaking of the Quechua verb 'waqay' ('to cry, sob or wail'). ${ }^{\text {xiv }}$ As the work of Stobart demonstrates, the verb waqay (to weep) is intimately tied to Andean notions of production (Stobart 2006:26). As I shall show, the practice of weeping to implore the huacas for rain was 
widespread throughout the Andes, suggesting that this tradition is linked to the Inca era. While the Inca era spanned 1400-1532 CE, archaeological data suggests that the Inca expanded into Huarochirí before 1450 CE (Hernández Garavito, personal communication). Ritual weeping may have been a regional practice that was standardised and spread across the empire by the Inca state. Whether rituals in Huarochirí featured weeping prior to the Inca era or whether this was introduced by the Inca, the custom has a long history in Huarochirí and in other Andean regions where people today invoke rain in the same way as their Inca-era forebears.

Entries in the Quechua dictionary of Jesús Lara support my argument that the ritual speaking of waqay is an Inca era tradition. The nominalized verb waqaylli is glossed as an "invocation which, in Inca times, was directed to the gods, imploring rain"xv (Lara 1971:312), while waqallikuy refers to a "nocturnal procession which would take place in the streets, asking the gods for rain in times of draught" (Lara 1971:312). ${ }^{\mathrm{xvi}}$ Waqay is therefore a word for particularly desperate times as well as for ensuring the timely arrival of the rainy season and of irrigation water through the canal systems in the dry season. The practice of calling out waqay in Casta today indicates that this practice is not a remote former tradition of the Inca era; these practices continue in villages where Inca traditions have continued relevance.

Some of the ontological dimensions of Inca state socioeconomic practices can be illuminated through considering the role of the Quechua language in communicating and consolidating Inca governance through ritual invocations. Quechua was the administrative language or lengua general of the expansionist Inca state, and functioned as a "contact language for speakers of distinct languages within the state" (Mannheim 1991: 33). The speaking of Quechua during pinnacular sections of pan-Andean rituals in traditionally Aymara speaking regions during the Inca era would have been a likely outcome of economic interventions by the Inca state. 
It is possible that the verb waqay had resonance in the linguistically diverse province of Huarochirí prior to the Inca era. In Jaqaru, an Aymara language which was spoken in Huarochirí in the Pre-Hispanic era and in the colonial period, the verb 'waqa' can be translated as 'to sprinkle water or seeds' ('demarrar agua o granos' in Spanish, Belleza Castro 1995:191). ${ }^{\text {xvii }}$ Given that waqay in its ritual context is linked to the Inca period, I argue that interpreting this word in its Quechua etymology is justified; however, it is worth raising the question as to whether, in multilingual contexts where both Jaqaru and Quechua were spoken (such as Huarochirí), this particular word had special resonance, multi-layered meanings, and the potential for wordplay.

My analysis of waqay proposes that the Inca state established access to water to be contingent on compliance with ritual discourse based on Inca moral codes by incorporating these into regional traditions. The Inca state allowed the worship of pre-Inca regional deities to continue alongside the worship of the Inca huacas, and endorsed the worship of the most important regional deities (Hyland 2011: 7). The 'grafting' of Inca state religion (including the performative worship of the water deity Viracocha) onto regional ancestor worship was an important feature of the Incas' exercise of power and control over their subjects (Urton 2017: 45). Although the Inca lengua general was not hegemonic in the same way that Spanish came to be in modern Peru (Mannheim 1991:80-81), the speaking of Quechua was inseparable from the economic interests of the Inca state. The inclusion of Quechua language discourse in Inca-era regional rituals would have been an effective way to communicate the idea that water access required the approval of the huacas affiliated with the Inca centres of power. Specifically, why would Inca subjects have been required to cry in Quechua? The cosmopolitical logics behind this practice can be understood by acknowledging that the Inca established himself as kin, and specifically as a father, through standardised ritual discourse geared at re-configuring the ways in which subjects engaged with the world and its centres of 
power. As Hernández Garavito has pointed out, the Inca re-ordered the landscape in Huarochirí through linking official narratives based on fictive kinship to local sites such as rock outcrops (Hernández Garavito 2020: 4).

Ritual practices involving crying in supplications for rain feature in recent ethnographies from Bolivia, suggesting this imperial strategy was far-reaching within the former Inca Empire. In Qaqachaka in the Aymara speaking Bolivian Andes, Arnold and Yapita observed children being whipped in Church in front of mummy bundles associated with rain, while older participants would beseech the mummies on their knees. While they prayed, the authorities whipped the children "so that they wailed and prayed before the goddesses" (Arnold with Yapita 2006:203). In Casta, the waqay invocation is called out to Wallallo (among other landscape beings), and it is possible that child sacrifices or practices designed to induce the cries of children may have also featured in water customs in Casta. A collaborator in Casta explained that in ancient times, human sacrifices were made to Wallallo, and furthermore, the Huarochirí manuscript explains that child sacrifices were made to Wallallo by the Yunca people who worshipped him in remote Pre-Hispanic times (Salomon and Urioste 1991:43). Stobart has noted that the cries of llamas and children are thought to bring forth the rains in communities in the Bolivian Andes (Stobart 2001:94). This practice resembles Inca crying rituals: according to the 1615 illustrated chronicle of Guaman Poma, the Incas performed water rituals in October, when a hungry black llama would help to cry and to ask for water from the creator God during the procession (Poma 1615: [254 [256]]) ${ }^{\mathrm{xviii}}$. Furthermore, Poma's account explains that ritual laments called uacachicos [waqachiku] were enforced through Inca state law (Poma 1615: 182[184]). Notably, Poma uses the Spanish verb entablar when stating that Inca laws relating to huaca worship were recorded throughout the Inca Empire (where, in line with these laws, the temples linked to Wallallo and Pariacaca had high-status ritual specialists) (Poma 1615: 183 [185]). xix This point obliges us to consider whether The Entablo water laws, 
which are based on Inca precepts and instruct the need for ritual crying, may include further ordinances of the kind historically recorded in Inca khipu laws. Wallallo was a principal Inca state huaca during the reign of the eleventh Inca Huayna Capac, as was Pariacaca, the foremost huaca from Huarochirí; furthermore, both these Huarochirí huacas were considered by the Inca to be loyal and compliant (Poma 1615: 113 [113]).

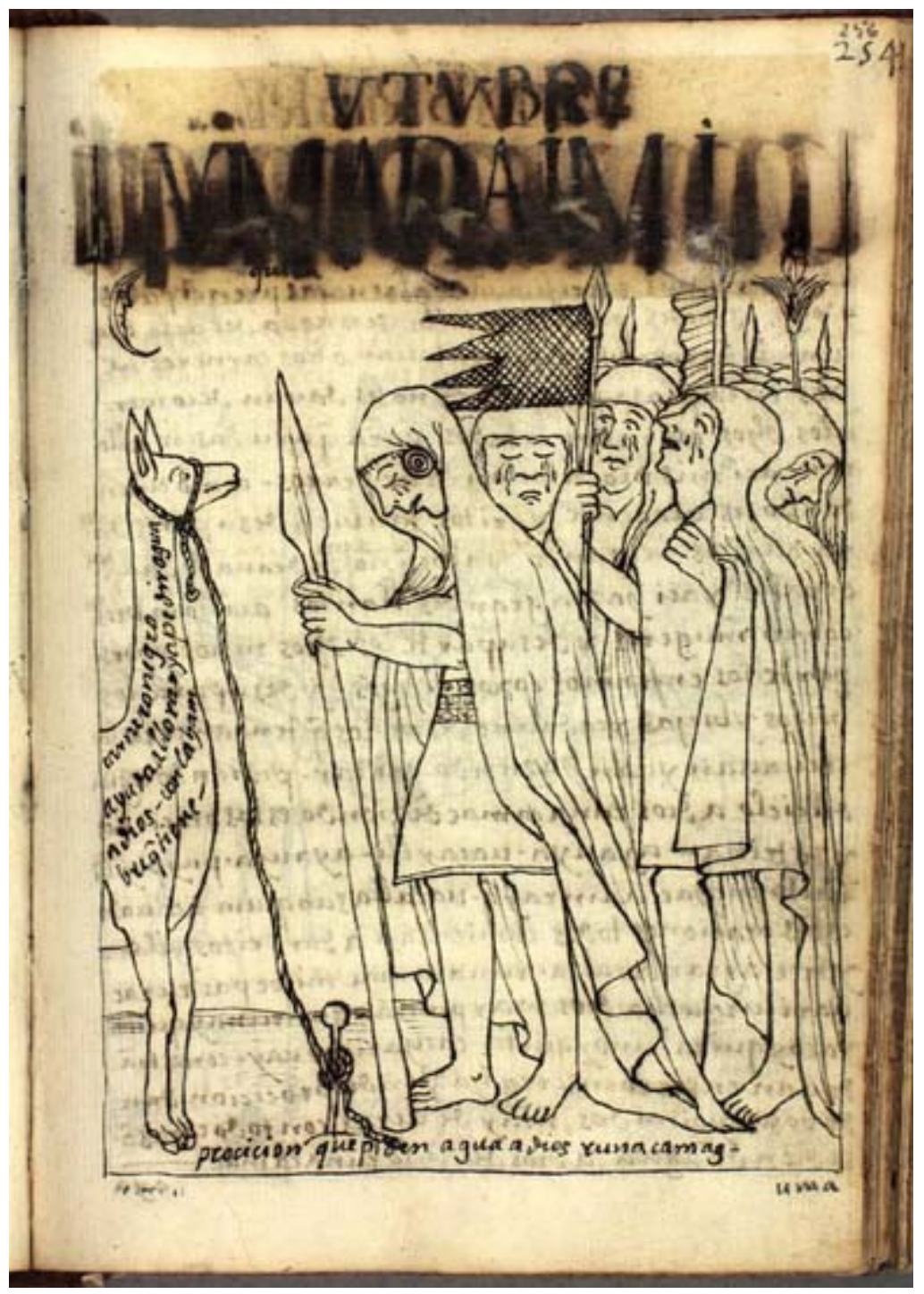

Figure 2. Guaman Poma's drawing of an Inca rainmaking ritual depicts teardrops on the faces of the participants. Image courtesy of the Royal Danish Library, GKS 2232:

Guaman Poma, Nueva corónica y buen gobierno (c. 1615), page [254 [256]]. 
The Inca state successfully incorporated Inca worship into regional ritual discourse beyond Huarochirí: today, rainmaking rituals in Bolivia involving crying children hinge on the links between local sites of power such as the mountain peaks and Cusco, the Inca state capital (Arnold and Yapita 2006: 200). In Huarochirí, subjects may have honoured the Inca in a more direct way through Wallallo or Pariacaca as mediaries. It is therefore fitting that Quechua language should feature in some elements of ritual dialogue with huacas linked to the Inca state.

The performance of a Quechua language crying ritual during a section of the champeria devoted to honouring a local huaca is indicative of Inca manipulation of the pantheon of local huacas; this religious strategy for facilitating Inca state expansion can also be observed in many of the biographies of huacas featuring in the Quechua Huarochirí Manuscript of 1608 (Salomon 1991: 10 ${ }^{\mathrm{xx}}$. Although we cannot be certain of the extent of linguistic diversity within multisite Inca era rituals in Huarochirí, it is likely that a number of indigenous languages were spoken in Casta beyond the Inca era and into the twentieth century. To what extent can an analysis of The Entablo illuminate the place-based logics of language choice in multilingual communities both in the past as well as today? To what extent are the distinctive functions assigned to different languages, and the degree of power ascribed to words as units of language, a legacy of the multi-layered economic and political history in the Huarochirí province?

\section{The Linguistic Landscape in Early Twentieth Century Huarochirí}

If we rely on archival evidence to contemplate the linguistic environment(s) in Huarochirano ways of speaking in the early twentieth century, we run the risk of being misled. The archival evidence appears to suggest that by the time The Entablo was written in Spanish in 1921, Quechua language use had begun to wane. Salomon and Niño-Murcia note that their research on community archives [of Tupicocha and neighbouring districts] has not yielded community 
records in either Quechua or Jaqaru (Salomon and Niño-Murcia, 2011:22). Furthermore, these scholars point out that early community documents in late nineteenth and early twentieth century Huarochirí were written in the "privileged language of the law" (Salomon and NiñoMurcia 2011:87). The absence of indigenous language paper documents in community recordkeeping is indicative of the fact that indigenous languages and Spanish maintained alternating functions through time, and we should not discount the possibility that neither Quechua nor Jaqaru were still being spoken conversationally in Huarochirí villages in the 1920s.

Hardman points out that at the turn of the twentieth century, Jaqaru was spoken not far from Huarochirí: "At the turn of the century there were still a few speakers in Canta, north of Lima" (Hardman 1966:15). I suggest that this statement could be expanded to some Huarochirí villages for the early twentieth century, and perhaps even today. Given the continued use of Quechua and Jaqaru lexica in Huarochirano ways of speaking, the province today might be considered a context of enduring "indigenous multilingualism" (Vaughan and Singer 2018). During my doctoral research in San Damián, Huarochirí in 2012, collaborators used the archaic word ñaña to refer to a female infant; this is a Jaqaru noun (Bennison 2016:215, Belleza Castro 1995:126). Similarly, the word yaya is also used in modern-day Huarochirano parlance to refer to an infant; this term is likewise of Aymara etymology. Collaborators associated these words with their grandparents' ways of speaking.

Scholarly research from the period tells us that Quechua was being spoken in Casta during specific parts of the champería in 1922. Julio C. Tello, the renowned Huarochirí-born archaeologist described as a "native Quechua speaker" (Burger 2009:3), and/or his coinvestigator Próspero Miranda, heard participants of the champería in Casta in the year 1922 interact with the huaca Wallallo in Quechua (Tello and Miranda 1923:527). That this instance of Quechua use was noteworthy might suggest that Tello and Mirando did not hear Quechua being spoken in other contexts during their time in Casta or during other sections of the 
champería. Although it is difficult to get a clear picture of linguistic diversity in Casta during the early twentieth century, the account by Tello and Miranda suggests that this particular section of the champeria was a locus for Quechua language persistence within a broader ritual context where another language or multiple languages were spoken.

Although Wallallo was specifically addressed in Quechua, I consider it unlikely that Tello and Miranda heard only one indigenous language being spoken in Casta in 1922. Did Tello and Miranda note the use of Quechua for communicating with Wallallo because another indigenous language was spoken conversationally alongside Spanish? This explanation would better account for Tello and Miranda's deeming the Quechua language interactions between the ritual functionaries and Wallallo in Casta in 1922 to be worthy of note. Jaqaru may have been spoken in Casta at this time, and Tello may not have understood the Quechua interactions well enough to be able to record them. Tello's status as a native speaker of Quechua is ostensible; according to a descendent of Tello, he was a native speaker of Cauqui (Jaqaru) who subsequently picked up Quechua later in his career when working in Ancash (Padilla Deza 2018:241). ${ }^{x x i}$ It is possible that at the time the Entablo was penned, three different languages (Spanish, Jaqaru, and Quechua) were spoken in the province, yet Spanish was reserved for writing. The importance of keeping community records in Spanish was particularly important from the 1920s onwards. Hall has pointed out the relevance of national level legislation in shaping the content of community padrones from 1920 onwards. From this year onwards, she explains, the necessity for the newly promulgated 'Comunidades Indígenas' to maintain lists of their populations for State scrutiny was enshrined in law, although often, associated community documents contained data which exceeded these legal requirements (Hall 2014:15). ${ }^{x x i i}$ Because these community records were subject to State scrutiny, these community archives, and closely associated archives, were written in Spanish. One wonders what effects State pressures on community records from 1920 onwards might have had on khipu devices, and whether their 
contents might have been transcribed into Spanish language documents written in legislative language, and with a local legal status, such as The Entablo. Did the national constitution of 1920 act as a precedent which inspired the authorities in Casta to set down and 'officialise' their Inca laws in Spanish language?

The Entablo clearly demonstrates that in the eyes of its composers, national level bureaucracy and legislation were compatible with, and relevant for, community modes of record-keeping, to the extent that its composers expressly sought for the content of The Entablo to be approved by State officials, including the village Mayor and the Public Health Minister. Moreover, a 1939 reform of The Entablo laws, wherein the duties of some functionaries were re-defined, came following changes in national level legislation, including amendments to the national constitution. In the section penned in 1939 , it is explained that the internal regulations penned within The Entablo would be subject to the approval of the Ministerio de Salud Pública, Trabajo y Previción Social (The Ministry for Public Health, Work and Social Precaution, formed in 1935). In this respect, we can appreciate that the language of The Entablo, which is largely penned in the language of the State, may not reflect ways of speaking at the time. Efforts to provide in-text glosses for ritual functionary roles in Quechua suggest that an effort was made to have as much of the content of the text in Spanish as possible, potentially with a non-local readership in mind.

The penning of The Entablo, along with other closely related community records from neighbouring Huarochirí villages, coincides with the first phase of the Leguía presidency (Salomon 2019), the policies of which were geared at articulating Peru's indigenous communities in a context of nation-building in the aftermath of Peru's defeat against Chile in the War of the Pacific. Burger has pointed out that in the late nineteenth century, the indigenous population was being strategically homogenized for defence interests: "The disastrous war with Chile had caused many of Peru's elite to conclude native Peruvians 
needed to be more fully integrated into the national framework if a recurrence of this military debacle was to be avoided" (Burger 2009:8). The oral testimony of Gregorio Condori Mamani suggests that early twentieth century militarisation in Peru was stamping out the use of Quechua among its troops. Reflecting on his time in the Army in the 1930s, Condori Mamani recalls that he and his fellow highland troops were beaten by the officers for speaking Quechua: such were attitudes towards indigenous languages at the time (Valderrama and Escalante 1996:52).

Given this context, it is therefore unsurprising that The Entablo was written primarily in Spanish, the language of the State and of Lima City. We can also observe a State endorsed preference for Spanish language in La Voz de San Damián, an outward-looking midtwentieth century text celebrating the centenary of the district of San Damián as an official public entity, edited by members of the Centro Social San Damián. The schoolteachers were keen to ethnically and linguistically clarify the status of the local population in their contribution to the volume, stating that Quechua was no longer spoken in the village and that absolutely everyone spoke Spanish at the time of writing, albeit with some 'errors in pronunciation' (CSSD 1957:200). Joshua Fishman's work on diglossia is helpful for understanding language transformation in Huarochirí at the turn of the nineteenth century, since it refers to linguistic situations marked by a hierarchy in language function of genetically unrelated languages and "provides the impetus for language maintenance or shift" (García and Schiffman 2006:20). ${ }^{\text {xiii }}$ Aside from the case of the Huarochirí manuscript, which represents a unique early book-length colonial Quechua written source, Quechua language apparently did not come to be used extensively in community documents in Huarochirí, and texts such as the La Voz de San Damián actively serve to divorce the population from its linguistic history through text: any mention of Quechua language knowledge in a text produced with the gaze of the State in mind would seem out of place in a domain traditionally 
reserved for the Spanish language. ${ }^{x x i v}$ In contrast, The Entablo of 1921, a self-described internal text, was written for a specific local audience, and although it has been penned in Spanish (in line with state requirements and constitutional precedents), it features an abundance of Quechua ritual lexicon, as one might expect from an Andean community setting down an official record of ancestral traditions relating to sacred spaces within the local landscape — apparently for the first time on paper.

\section{Communicating with the Huacas: Sound and the cosmological functions of crying}

In Huarochirí, landscape beings manifest themselves through sound, just as they do in Quechua-speaking parts of the Andes (Howard 2012:252, Platt 1997). Bray has pointed out that the ability of a huaca to communicate and vocalise is central to their identity (Bray 2015:9). This also holds true for Spanish-speaking Huarochirí, where narratives of landscape beings almost always allude to the noises created by those beings (Bennison 2016:219). Platt's research in the Bolivian Andes points out the importance of talking when communicating with landscape beings: during séances with mountain spirits, "the most important thing of all ... is to keep talking" (Platt 1997:221). Clearly, landscape beings listen to humans, and likewise, humans listen attentively to landscape beings.

In a similar vein, landscape beings themselves may be recognised or strongly associated with ideophones or 'sounds'. Relevant here is the work of Nuckolls (2010:9), for whom ideophones allow indigenous Quichua speakers in Amazonian Ecuador to communicate with, and articulate, the quoted speech of non-human beings. Oral narratives from Casta noted down by the archaeologist Julio C. Tello provide insights as to how Casteños, approximately a century ago, identified the different beings with whom they had interactions by vocal characteristics. One narrative describes a battle between the beings Socta Curi (who is remembered as a hero) and Huambo (who is remembered as an expelled tyrant), where Socta 
Curi was said to return to Casta each January to bestow the villagers - who had borne the brunt of Huambo's rage—with abundant rains each January. Tello was told: “...And so, from time to time, he [Socta Curi] has come on his periodic visits here in the month of January. The locals recognise him from his powerful voice which is very different to Huambo's gloomy voice. These visits bring on copious rains which result in abundant harvests which benefit the inhabitants of Casta.". xxv, xxvi

Salomon was repeatedly told during his fieldwork in Huarochirí that Pariacaca, the name given to Huarochirí's foremost huaca, is a sound: "Pariacaca is the sound the water makes in the stream in winter. By listening to it, you can tell whether it will be a good year for crops. We have that belief" (Salomon and Niño-Murcia 2011:232). In San Damián, I was told that in the rainy season, the malevolent rainbow being strikes out of a highland subterranean spring before crashing out towards the sea or another spring, making a noise that collaborators described as a "Whoooooooom" or "Qraaaaack" sound. The interactions between locals and these beings are therefore seasonal or are more likely to come about during certain seasons. The Entablo informs us that a waqay is only required during particular moments at certain sites along the ritual trajectory in October, and, as I will elaborate, a waqay is necessary for the January traditions which mark a crucial moment in the agricultural cycle - the onset of the rains.

The nominalized verb waqay appears twice in The Entablo regulations for the October champeria, with a hispanised spelling: huajay. The sacred text stipulates that on the Wednesday, once a functionary known as the Alcalde Campo has fulfilled his moral duties, he "will summon the singer and the Alféreces [Standard Bearers] of both paradas [community sub-groups] to hold up a multi-coloured flag well-adorned with bells and feathers and they should continue the hualina ${ }^{\mathrm{xxvii}}$ song" (CCSPC 1921:f.8). It is explained that in so doing, the Alféreces of both paradas will pay their respects to the elders, and in the 
same way, the Michcos [functionaries in charge of leading the work of the community subgroups] shall offer coca to the elders. Once this part of the champeria is complete, they will set off for a place known as "Otagaca," where an announcement will be made through a cry of "Huajay" which will gain the attention of the spectators. ${ }^{\text {xviii }}$ Then, "the functionaries, along with some devotees, will halt the hualina and they will proceed to summon a sense of order. Once they are ready to get to work, they will kneel down and recite a number of prayers so that they are well received and, as they end their prayers to God, they wholeheartedly entrust their faith to his care" (CCSPC 1921:f.8). ${ }^{\mathrm{xxix}}$

Thus, the 'waqay' (huajay) act of crying out signals an alert for the ritual participants to gather for a time for prayer and worship. The Entablo stipulates various periods of prescribed periods of joy and contrasting solemnity throughout the duration of the week-long champeria. The inclusion of the word in an otherwise largely Spanish language document is likely linked to the pinnacular nature of the interactions with the (historically Inca-affiliated) landscape beings intended to hear and respond to these pleas for rain. We will see that there is no equivalent term in Spanish which could communicate the ontological implications and associated ritual practices that revolve around this singular word. ${ }^{\mathrm{xxx}}$ There appears to have been an awareness of this fact by those who penned the word in The Entablo: in both instances where waqay [huajay] features, the word appears in inverted commas, indicating that it is not Spanish vocabulary.

The verb waqay is conceptually integral to the economic politics of the champeria, since it relates to the practice of communicating with the sacred landscape. As detailed above, waqay features in The Entablo as a nominalized verb, consisting of the verb root waqa-suffixed with the infinitive nominaliser $-y$. As Adelaar and Muysken explain, infinitive constructions with the $-y$ nominaliser have the characteristics of an infinitive (Adelaar and Muysken 
2004:226). Thus, in the context of the ritual instructions, a waqay is an action to be effected in the champeria.

Although waqay features in The Entablo as a nominalised verb in the sense described above, when the ritual functionary shouts out the word, waqay serves to address the interlocuter who is being addressed, i.e., through second person inflection of the infinitive through the imperative -y suffix (Adelaar 2017:50). As such, when waqay is called out during the champeria, the speaker is employing the imperative inflection of the verb form in Quechua, whereby the $-\mathrm{y}$ added to the verb root waqa- (to cry, sob, or wail) is a one word petition to Wallallo, to implore him to release tears (as rainfall): "cry!"

In chapter three of the Huarochirí manuscript of 1608, waqay ('huacay') was the verb used to describe the crying of a llama buck who foresaw a cataclysmic flood and communicated this knowledge to its (male) human owner, its guardian (Salomon and Urioste 1991:51). Given the connotations of desperation inherent in the verb in its Pre-Hispanic usage mentioned above, the narrative of the llama and its ignorant owner in the 1608 text must have sounded ominous to any Quechua speaker who heard this account: if the llama was crying out waqay, its owner was foolish not to have recognised that he was being alerted to harm and a crucial matter relating to water. Likewise, 'waqay' was the verb used in chapter six of the Huarochirí manuscript to describe the weeping of a beautiful woman named Chuqui Suso who was distraught to see her maize plants were drying out due to her scarce water supply. When the huaca Pariacaca saw this, he acted to help Chuqui Suso by damming her pond. When she began to cry even more bitterly, Pariacaca responded, attuned to her distress and to her need for water, which he offered to provide in return for sex (Salomon and Urioste 1991:62). Chapter twenty-four describes the varying material gifts that Pariacaca gave to groups who invoked him in tears, addressing him: "Father" (Salomon and Urioste 1991:118-119). 
Pariacaca responded to these invocations by addressing the members of the various group: “Children” (Salomon and Urioste 1991:118-119).

The practice of crying during invocations appears to have been closely associated with the apical huaca Pariacaca, and these narratives suggest that crying was central in the establishment (and in the performative reproduction) of reciprocal relationships expressed through kinship. Similarly, crying played a key role in the development of kin relations between the Inca and his 'children' in Huarochirí and throughout the empire. Recent archaeological research of ritual sites in the province, combined with an analysis of the Huarochirí Manuscript suggests that the Inca established himself as kin to facilitate Inca state expansion in Huarochirí (Hernández Garavito 2020). The linguistic evidence supports this claim, and offers insights into the ways in which the Inca state legitimised its economic model and claims to taxes: groups who acknowledged the Inca, and the Inca huacas as their father would have their needs fulfilled. As Stobart explains, weeping (waqay) in Andean agricultural practices is usually directed towards male guardians or ancestors associated with hearing and compassion (Stobart 2006:31). As discussed earlier, we know that Quechua invocations in Casta, including the shouting of "waqay!", were directed towards the Incaaffiliated huaca Wallallo (Tello and Miranda 1923). Through considering aspects of these invocations, we can appreciate that the productive powers of the ancestor huacas were accessed through performative expressions of kinship, where the ontological strength of huaca kin is made momentarily penetrable through the targeted ritual practices of their 'children' in need.

Tello and Miranda's article, based on research conducted in Casta in the early 1920s very shortly after The Entablo was initiated, includes a detailed description of the champeria, including the preliminary proceedings of the Sunday night prior to the main ritual events. On the Sunday night, according to Tello and Miranda, a functionary known as the Wachiq must 
lead a committee of fellow functionaries on a secret pilgrimage to the site of Mashka [located between Casta and the site of Marcahuasi] where Wallallo was known to reside ${ }^{\mathrm{xxxi}}$ (Tello and Miranda 1923:526). Proceeding from here, the Wachiq would continue to invoke Wallallo:

The committee sets off and, from time to time, the Wachiq invokes the divinity with shouts of Waxay! Waxay! [an alternative spelling of waqay]. In utmost silence and almost completely still, everyone strives to hear, with a sense of clarity, the answers which are no other than the different vocal repercussions of the sounds made by the hills(ides). At certain points, they believe that they can clearly hear the voice of Wallallo in the echo, and in other moments, they hear the voices of the secondary divinities that reside in the hills. In this manner, and always stopping at certain points to repeat the same act, they arrive at the small square located at Mashka which is located in front of the sacred stone. The authorities stay back a certain distance, while the Wachiq approaches the stone on his own, and with notable concentration, pronounces some ritual words in Kichwa [Quechua]; he offers it coca, sprinkles it with chicha [corn beer] and bending over in reverence, repeatedly shouts Waxay! Waxay!

Those present sit and wait anxiously to be accepted by the divinity, trying to hear the, for them, familiar voice of Wallallo. After a short moment, the Wachiq announces that the divine voice which emanates from the stone can finally be heard; then 
the functionaries approach it and offer it chicha and coca.

[Tello and Miranda 1923:526-527]

First, it is worthwhile contemplating the role of the Wachiq. As I mentioned earlier, collaborators in Casta explained that 'strong words' are used to communicate with landscape beings. It is particularly fitting that a functionary called the 'Wachiq' is responsible for communicating directly with Wallallo, given that this title is associated with the projection of strong words. In the early colonial dictionary of Gonzales Holguín, the Quechua verb 'huacchini' is translated as "to shoot” [tirar] (Gonzales Holguín [1608] 1952:168). ${ }^{x x i i}$ In Quechua, the verb root $w a c c^{\prime} i$ - or $w a c \hat{i}$ - refers to stabbing, piercing, or puncturing, with respect to arrows and also to sowing seeds using a foot plough to cut and turn over the earth. Similarly, in Jaqaru, the verb root watri- refers to the planting of seeds while using a foot plough (Belleza Castro 1995:188). Thus, wachi-q can be translated as 'the one who plants seeds' or 'the one who pierces'). ${ }^{\mathrm{xx} x i i}$ Given that the verb wachiy ('to plant seeds' or 'to pierce') is conceptually related to waqachiy ('to make someone cry'), it merits further analysis here.

The practice of cutting open the land before crying to the huacas is reported in the ethnographic record; during rainmaking rituals in Livichuco, Bolivia, a section of earth at a ritual complex is scratched open while young children cry and older children and adults pray close by (Arnold and Yapita 2006: 200). Meanwhile, the ritual connection between crying and shooting is evidenced through the existence of a highland ritual site in Cabana (Ancash, Peru) named 'Huachic Huacachic' (Cuba 2014: 191). This toponym can be translated as 'The piercer, The crymaker' and presumably, crying and piercing in some sense were central aspects of huaca worship at this site. ${ }^{\text {xxxiv }}$ 
The link between ritual crying and shooting becomes clearer if we consider that both practices are impactful on delivery. The power of 'strong words' to target the sensibilities of individuals is explained in an early colonial description of the wachiq [huachik] role, where an example sentence in Quechua refers to a preacher who "pierces his heart with the arrowlike words of God that hit him straight in the heart and do not wound him"xxxy (Gonzales Holguín [1608] 1952:168). The functionary therefore projects his words from the heart while entrusting himself to the guardian huaca who will respond in the same way, from the core. In a similar vein, The Entablo stipulates the need to for the shouting of 'waqay' to accompany the recital of various prayers to God through which the speakers "wholeheartedly entrust their faith to his care" (CCSPC 1921:f.8).

Early colonial accounts of ritual in Huarochirí describe the practice of firing targets at two effigies representing sacred ancestors: chapter twenty-four of the Huarochirí Manuscript describes a spear-throwing competition between multiple ayllus at the ritual complex of the Checa, Llacsa Tambo (Salomon and Urioste 1991: 122-124). An analysis of Quechua kin terms featuring in this description of ritual discourse suggests that both effigies were considered to be male kin (Salomon 1991: 122). During this ritual, men would fire spears at the effigies while the women would verbally address the sacred ancestors via their effigies, chanting: "Receive your poor forlorn children!" before announcing the bestowments they expected the ancestors to respond with (Salomon and Urioste 1991: 122). These practices indicate that spoken performances of sadness and dependency were targeted at male guardians alongside the firing of weapons designed to physically puncture the targeted $\operatorname{kin}^{\mathrm{xxxvi}}$. The manuscript mentions that following the spear-throwing, llamas were left at Llacsatambo and other ritual complexes, and people would instruct the llamas: "Worship on my behalf and I shall be well" (Salomon and Urioste 1991: 123-124). This description 
resembles Poma's aforementioned depiction of Inca crying rituals, where llamas 'helped' during the laments. Based on other sections of this text, we know that the cries of llamas were considered a powerful form of communication capable of gaining the attention of their guardians and we can reasonably deduce that llamas were used in ancestor-focussed crying rituals at Llaquistambo. ${ }^{\text {xxxii }}$

The role of the Wachiq in Casta may have once involved breaking open the earth at Mashka or firing targets at ancestor effigies as well as orally penetrating the realm of the huaca: as I have shown, all three related practices were geared at ensuring the success of the crops. It is possible that the functionary who calls out "waqay!"- the Wachiq—does so to temporarily inflict pain on Wallallo, to provoke his tears ${ }^{\mathrm{xxxviii}}$. The Wachiq targets Wallallo at a sacred stone at Mashka using the powerful words that this huaca should use in response.

Reflecting further on the above account by Tello and Miranda, these authors witnessed the ritual approximately a year after those involved in the writing of The Entablo set down the need for the shouting of waqay, and as such, we can appreciate that practices associated with this tradition were elaborate and solemn events whose detail exceeds that given in The Entablo regulations.

On a very basic level, Tello and Miranda's account epitomises human-huaca reciprocal relationships and illustrates the widely held understanding that a feature in the landscape such as a stone can represent, or be, kin. Narratives featuring in the Huarochirí manuscript explain that various huacas dwelled in stones; chapter two details the fleeing of a huaca named Caui Llaca from Huarochirí towards the coast, turning herself and her baby into stones in the sea near Pachacamac (Salomon and Urioste 1991:468). ${ }^{\text {xxix }}$

Tello and Miranda's account is of particular importance for consideration of the concept of 'waqay', since a huaca [waqa/waka] or landscape being acquires its power through its ability 
to speak and respond to the elaborate and sustained supplication triggered by the word 'waqay' and the targeted, attention-grabbing vocalisation released at the moment of its pronunciation. The Quechua word is employed within a specific context—-that of imploring and interacting with the animate landscape, and specifically with Wallallo, a lowland huaca associated with fire, whose battles against the highland huaca Pariacaca were described in chapter eight of the Huarochirí manuscript of 1608 (Salomon and Urioste 1991:66). In 'crying out' in Quechua, the functionary is acknowledging the existence and power of Wallallo, while also inviting Wallallo to participate in the champeria at this place and moment: "To hear is to exist in a specific place and moment in time" (Stobart 2006:32). Furthermore, to cry out the word 'waqay', and to have instructed the need to do so in The Entablo, is indicative of the cosmological basis on which agro-pastoral production in Casta has been negotiated and understood. As Mannheim explains, “when a speaker invokes part of the network of lexical meanings surrounding reciprocity and other forms of cyclicity, she is unconsciously reaffirming the ontological status of the larger network of meanings" (Mannheim 1991:90). We can assume that the Spanish word 'llorar' (to cry) does not convey the same connotations and qualities as waqay, given the differing geo-cosmological roots of these respective words, and the specific, localized ritual context within which waqay is verbalised. In this respect, a 'monolingual' Spanish language repertoire is inadequate for conducting successful interaction with landscape beings, and extant indigenous language words are relied upon for winning the favour of Wallallo and achieving adequate rainfall and irrigation water.

According to Vital, the Quechua verb ‘waqay' denotes the making of loud sounds, and specifically the kinds of sounds that are worth noticing (Carlos Molina Vital, personal communication 29 January 2019). ${ }^{x l i}$ In the ritual context within which waqay is being shouted out as described in (or instructed in) The Entablo, the manner of the delivery of the word is 
crucial in achieving the desired effect: the word must be shouted out loudly in order to implore Wallallo; it is surely the high-pitched, penetrative delivery of the word, which has an

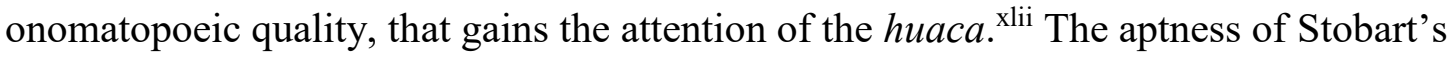
research on the verb waqay and the ontology of sound is highly relevant for this context, and as such, it merits citing at length:

I ... learnt that all food crops are considered 'to weep' (waqay) if not cared for appropriately, highlighting peoples' emotional bond with the 'products' they bring into the world. Agricultural production was presented as a complex, shifting and interdependent web of relationships, where the wellbeing of humans depends upon productive relations with a multiplicity of beings, including the food crops they consume- - whose cries powerfully express mutual dependence. The same verb waqay ('to weep/cry') is also used to refer to the production of sound by any musical instrument; sounds that are explicitly played to articulate relations with others-human and otherwise, whether serving to console, enchant or bring joy. [Stobart 2006:26]

In his research on the ontology of sound in the Bolivian Andes, Stobart provides an in-depth consideration of the verb waqay and the significance of weeping in the performance of guardian-dependent relationships: "Weeping ... powerfully expresses the guardian-dependent relationship necessary for a dependent to live, develop and achieve its potential. In turn, the very act of 'hearing' (that is, responding to) such sounds, for example by providing food, comfort or care, confers status, responsibility and authority on the hearer" (Stobart 2006:30). This logic can be applied to the context in question, where the word 'waqay' expresses the acknowledgement, by the speaker and the group he represents (both the ritual party and the 
entire body of irrigators more generally), of Wallallo's presence and power and their dependence on him for the success of the champeria and for water availability throughout the year.

Relevant here is the concept of 'mañay' (to beg, request or pray), which has been described by Gose with reference to his research in Huaquirca, Peru, where individuals would solicit help with agricultural tasks using an "exaggerated high whining tone" (Gose 1994:135). The practice of petitioning help with agricultural work using a high-pitched voice to implore a response closely resembles the practice of shouting 'waqay' in the irrigation rituals of Casta. Although Gose does not specifically mention that the practice of mañay entails crying, it is possible that there may be a semantic association with crying or whining — in San Damián, when my baby would cry in public, imploring me to respond and attend to his needs, locals would comment “Just look at how he does the maña!” (¡Cómo hace la maña!).

For Carlos Molina Vital, 'maña' represents a petition performed as a prayer and thus can be understood to be "the opposite" of an offering (Molina Vital, personal communication 21 February 2019). This definition tracks with that of Gose, who glosses the word as follows "request ...; something that lacks its pair" (Gose 1994:301). Generally, it might be said that when a person or being vocalises a request, this act triggers the social conditions for the need to be met and invites a response on behalf of the listener. Intriguingly, Mannheim has reported that ritual offerings made to mountain beings in Quechua-speaking Cuzco are often accompanied by a mañay request for fertile lands (Mannheim 1986:268). Thus, the voicing of the word 'waqay' functions as a key cosmological communicative practice within a mañay supplication. The calling out of waqay is a lament designed to immediately attract the attention and care of the landscape being within the social framework of mañay. 
Further consideration of Stobart's research illuminates the affective, productive nature of the audible expression of emotions in particular moments in time and place. Thinking more broadly about how Casteños interact with Wallallo during the Champería, we might reflect on the aforementioned specification collectively agreed upon and set down in The Entablo, whereby participants in the champeria must engage in periods of prescribed joy and exuberance, followed by periods of solemnity. On a fieldwork trip to Casta in 2009, I was told that both happiness and crying are integral elements of the champeria, yet I had not been able to comprehend the logic of this emotional rollercoaster, and particularly why it might be required during the champeria: an ancestral ritual geared at securing water in the coming year. Further reflection upon the work of Stobart is crucial for understanding the dynamic of tension between the periods of joy and solemnity prescribed during the champeria, which, I believe, are linked to the performance of interdependence between Wallallo and Casteños. As Stobart explains, energetic and emotive sounds represent a call for action in relation to future hopes and needs yet to be fulfilled:

One the one hand, immature, unpredictable and demanding dependents — whose hunger, desires, anger and energy are especially vividly expressed through sound - bring energy, transformation, enchantment, joy and consolation. They are the future- that which has yet to be 'produced' and made visible. On the other hand, mature guardians/ancestors, associated with hearing and compassion, provide material sustenance, stability, moral values, control and authority. They are imbued with pastness - that which has been 'produced' and made visible. This imagery evokes the idea of a world that is in constant tension with itself — an ontological tension on which its very existence and continuity is founded. [Stobart 2006:31] 
It is perhaps for this reason that Casteños await Wallallo's oracular response so eagerly: their future wellbeing hinges on this interaction. It is also surely for this reason that the verb 'waqay' remains in Casteño ritual language today.

In 2018, an entry-level ritual functionary (the Alguacil) in Casta told me that the word 'waqay' [wajay/huajay] features in the ritual traditions of Casta today. He described the Pirwa ritual carried out by the ritual authorities each January, where a ritual expert known as the Yachak (an alternative spelling of Yachaq, 'Knower'xliii) leads songs and dances dedicated to a sacred rock located at the site of Purpito Mama in Casta. A collaborator in Casta, who asked not to be named, explained that the word 'pirwa' refers to maize, ${ }^{\text {xliv }}$ while the 'mama' in the toponym Purpito Mama is 'the grandmother'. Specifically, Purpito Mama is a progenitor stone upon which a ritual altar (mesa) or 'pulpit' is set out during the Pirwa ritual in January, where the focus is to bring on the rains. During the conversation with the anonymous collaborator, they sang a short song in Quechua which is dedicated to the Purpito Mama stone and sung during the Pirwa ritual honouring her. While singing the song, participants dance close to the stone, passing around a series of sacred objects (which are inventoried in The Entablo) as they dance.

The stone itself is said to respond to the various ritual offerings made (and spoken) by the participants. During our conversation, the Alguacil functionary explained that the shouting of waqay takes place towards the end of the rites, during a decisive moment:

"Ya al fin de la pirwa ... o sea allí [Purpito Mama] hicimos la despedida. Así fuimos allí. Allí cantaban. Allí así cantan su hualina, cantan los ... hay unos de la champería, ¿no? Y el que representa el Campo dice, ¿no? Allí tiras con un ‘wajay’ de allí, vamos." 
Sarah: ¿Un 'wajay’?

Alguacil: Es un temor que un cerro te contesta. Y lo que usted dices, litas. Te contesta el eco y si no te contesta, está mal o algo así. Es algo sorprendente así pero allí hacemos.”

"So then at the end of the Pirwa, or like I say, there [at Purpito Mama], we would do the farewell. So we would go there. They used to sing there. So they go there and sing their hualina songs ... there are some [songs] from the champería, right? And the one who is the Campo [functionary] says that from there you should just fire out with a 'wajay!' and off we go."

Sarah: "A wajay?”

Alguacil: "It's a fear that the hill responds to. And what you say, you're giving as an offering. The echo answers you back and if it doesn't respond, something is the matter, or something like that. It's something that's surprising but that's where we do it." 


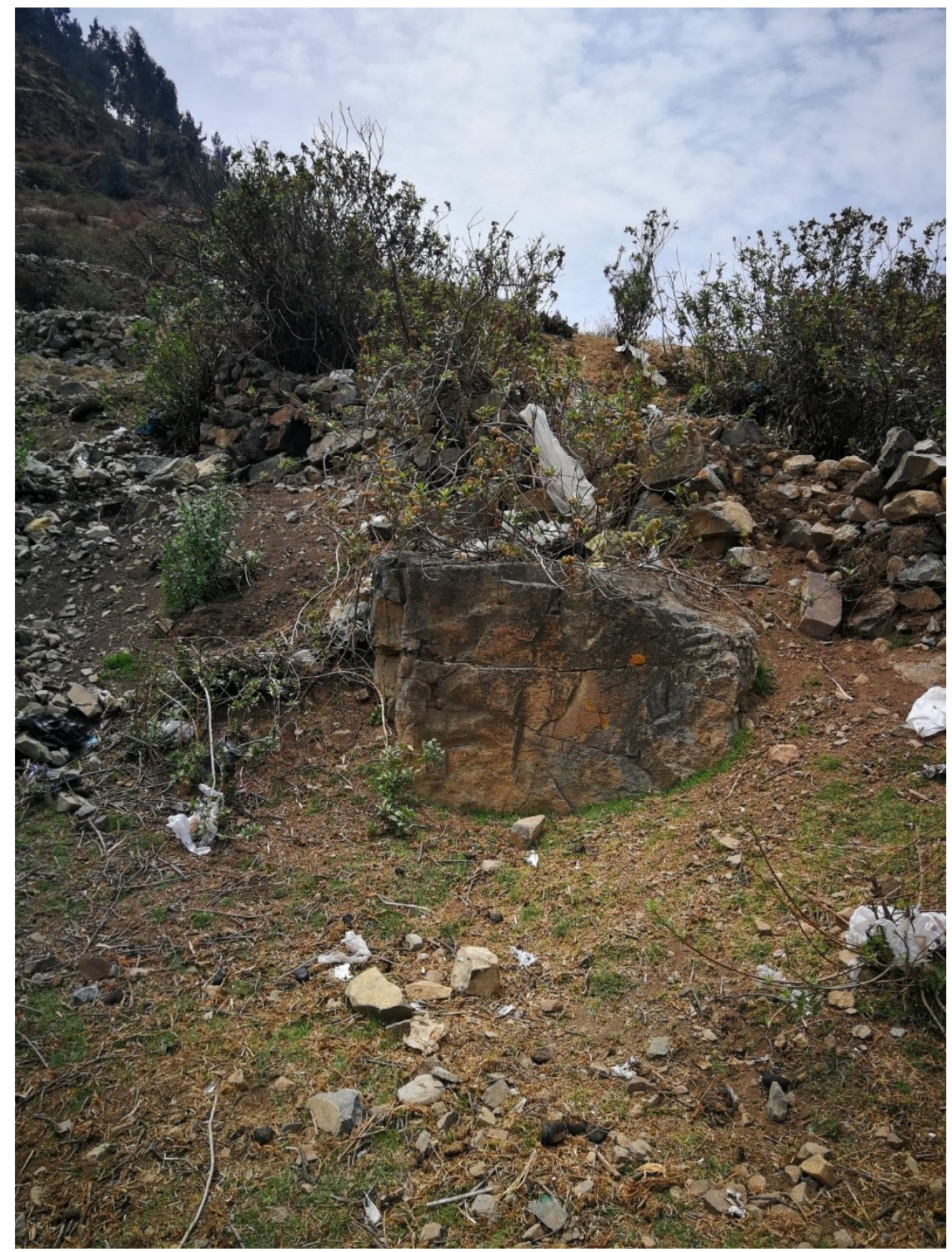

Figure 3. Purpito Mama (Photograph by the author).

The Alguacil continued to explain that based on the response of the stone, the Yachak, the

Curandero (ritual specialist and healer) and the Campo (functionary) interpret the response and, if relevant, call for the potatoes to be planted. If the stone "sweats" and appears wet, this is interpreted as a foretelling of a productive oncoming rainy season. As with the case of Wallallo's stone at the site of Mashka, the "grandmother" stone at Purpito Mama is the object of the targeted waqay supplication, suggesting that both sites are loci of Quechua language traditions. Thus, we can appreciate that the Inca era tradition of crying out remains a pinnacular aspect of agricultural traditions in multiple sites in Casta today. This point is 
important for considering the implications of rigid categorisation in that the persistence of indigenous language use in Huarochirí villages today is invisibilized when these communities are represented as being monolingual (only Spanish speaking). Language use in Huarochirí suggests that the scholarly interest in language categorisation is not always shared on the ground by the speakers employing the words we analyse. When speakers discussed 'waqay' and other indigenous language words with me, they glossed their meanings in Spanish, yet they did not etymologically categorise them.

Peasants in Huarochirí, like Quechua speaking peasants in Cuzco, negotiate the 'duality of powers' that affect their everyday lives (Mannheim 1991: 81). As I have shown, Quechua is used in Huarochirí to address the manifestations of 'productive' power; the landscape beings whose power economic livelihoods depend on, as is the case for Quechua speaking peasants in Cuzco (Mannheim 1991: 81). The Entablo manuscript, as a community's twentieth century Inca constitution written in Spanish, is ontologically entangled with multiple sites of institutional power: the Inca ritual laws linked to the landscape beings, and the increasing presence of the Peruvian state in community legal and economic practices. In this sense, the inclusion of Quechua crying rituals in this Spanish manuscript tells us that these two domains of power are not considered to be mutually exclusive. Categorising ways of speaking in Huarochirí would require a conscious disentangling of the kinds of powers that speakers negotiate in their daily lives; this includes the burden of language discrimination. Having unravelled some of these entanglements in this paper, I hope to have made it evident that local logics of language are informed by the distinct characteristics of multiple modes of state power and their intersections over time. Where the speaking of Quechua sentences may be endangered or no longer possible, the speaking of a singular Quechua word can offer a channel through which to tap into the power of the landscape beings in a way that is 
compliant with the Inca ritual laws that have been dutifully observed in Huarochirí for centuries.

\section{Conclusions}

The persistence of Quechua language in ritual contexts in the highlands of Lima is indicative of both the power ascribed to loaded 'strong' words such as 'waqay' and to the beings in control of rainfall. Furthermore, that production and wellbeing hinge on a continued "Quechua ontology" (Mannheim and Salas Carreño, 2015:47) cautions us to question the narrowly defined indigenous language based categories which are currently being employed by the Peruvian State in their categorisation of the groups who can claim indigenous rights, whereby only groups speaking indigenous languages can do so (Bennison 2016). As I mentioned earlier, the Quechua Huarochirí manuscript of 1608 is lauded as a unique window into the Pre-Hispanic and early colonial era Andes. In both the Huarochirí manuscript and The Entablo, we can trace the continued importance of crying out in order to gain the attention of a landscape being. I suggest that this is indicative of the power of the Inca legal and political system through which the Inca brought himself closer to his subjects, inserting himself into regional economies through ancestor-focussed ritual discourse.

Through my discussion of the persistence of an indigenous language word used in water rituals in Casta, I hope to have made clear that it is indeed arguable that ways of speaking in Huarochirí are indicative of a Quechua ontology characterised by "specifically Quechua ideas of the kinds of objects that exist in the world and their interaction with each other" (Mannheim and Salas Carreño 2015:48). In the specific case of the Quechua weeping rituals performed in Casta in the twentieth and twenty-first century, Quechua words carry within them the ontological and emotional force that is required for appealing to the sympathies of Inca kin in the distant past. 
In Casta, the calling out of the Quechua word 'waqay' has the potential to affect the material world controlled by the huacas, since it appeals to the fundamental basis of that relationship: child or receiver of care and guardian or ancestor. In my discussion, I have described the significance of this term when called out in interactions with huacas at specific moments at specific places, highlighting the social role of crying for the affirmation and reaffirmation of mutually dependent relationships. For this reason, it would be perfectly reasonable, from a linguistic point of view, to include Huarochiranos in discussions of Quechua ontology. Nevertheless, on a political level, this is problematic.

Any attempt to apply a Quechua language identity or a Quechua language ontology to Huarochirí would require ignoring the ways locals speak (or indeed refrain from speaking) about their ways of speaking. For this reason, I advocate for linguistic anthropology to listen to what is not said by interlocutors, as well as what is. Waqay is shouted out loud, but Quechua language persistence is simply not discussed. Singular language-focused ontologies are problematic for postcolonial settings defined by multilingualism, which are often marked by long histories of language hierarchy. To ignore this is to essentialise language use on the ground. Furthermore, to suggest that Quechua language is actively being spoken in Huarochirí today would require overlooking, or speaking over, speakers for whom language categorisation offers no clear social or economic purpose. Identifying clear-cut language categories here would also be a complicated matter in practice.

Through drawing on a body of linguistic and ethnographic material, I have identified the ritual voicing of 'waqay' to be an instance of Quechua language use, although it is possible that the verb might hold more dynamic connotations for speakers of both Quechua and Jaqaru. Might there be Jaqaru words spoken in Huarochirí during interactions with huacas today? This is possible, but acknowledging this possibility raises a question concerning language history and multilingualism: speakers in Huarochirí may address some huacas in Spanish, some (formerly 
Inca-affiliated) huacas in Quechua—and potentially, some may be addressed in Jaqaru. Hypothetically speaking, such linguistic diversity could be observed within just one irrigation ritual honouring a variety of huacas and ancestors linked to different sites along the irrigation system and with origins in different periods of time.

In this respect, ways of speaking in Huarochirí rituals are defined by the historical relationships between people and the huacas over time; this diversity is not reflected by the rigid languagebased categories referenced in political and academic discourses. The fact that waqay features in The Entablo of 1921 and in ways of speaking in Casta today is testimony to the persisting centrality of crying for securing water access. It was surely for this reason that the creators of The Entablo included the calling out of waqay in this set of regulations, thereby ensuring that the guardianship of Wallallo continues from ancestral times into the future. After all, the water he controls quenches the thirst of those in Casta from the moment of their birth, sustaining them through life. Could any other word be more powerful?

\section{Acknowledgments}

This research is an output from the project "Hidden Texts of the Andes: Deciphering the "Khipus" (Cord Writing) of Peru' led by Professor Sabine Hyland and funded by the Leverhulme Trust. I would like to give thanks to Sabine Hyland, Jonathan Alderman, and Carlos Molina Vital for their feedback on this work, and to César Urrutia for his encouragement. I would also like to express my gratitude to the two anonymous reviewers whose respective feedback helped to sharpen and strengthen this paper. This research would not have been possible without the generosity and trust of the authorities of the Comunidad Campesina de San Pedro de Casta nor the comuneros who generously shared their time, insights, and treasured patrimony with me. The names of the comuneros who gave me permission to use their names feature in this paper, and those who requested anonymity have not been named. 
ii This law implements Convention 169 of The International Labor Organization (ILO) on Indigenous and Tribal Peoples, of which Peru is a signatory nation.

iii I use the term 'being' to refer to a living thing known to exist and known to have agency.

${ }^{\text {iv }}$ It is worth noting that all these references relate to the highlands of Lima.

${ }^{v}$ San Pedro de Casta sits at 3185 metres above sea level in the Santa Eulalia river valley.

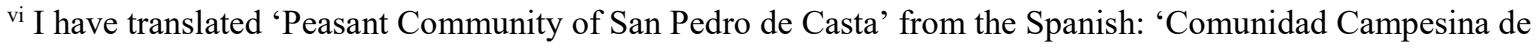
San Pedro de Casta'. A Comunidad Campesina is a "self-governing corporation controlling the rural orbit: community fields, pastures, and infrastructures including canals, terrace walls, and reservoirs. It also leads the ritual part of in-town life, notably the patron saint festivals" (Salomon 2004:44).

vii My translation from the Spanish: "Es una norma o ley".

viii My translation from the original Spanish: "muchos leyes de la era incaica” (CCSPC 1921:f.19).

ix The Spanish word 'padrón' may be translated into English as 'census'.

${ }^{\mathrm{x}}$ The content of The Entablo, written in 1921, suggests that khipu boards were used during the champería at least until 1939 so this hypothesis may require further research. Nevertheless, the perception that The Entablo is part of a khipu legacy is important, since The Entablo explains how various khipu board accounts were used in the champeria to record participants' contributions. Furthermore, The Entablo potentially contains 'transcribed' elements of San Pedro de Casta's khipu patrimony relating to the respective kin groups (ayllus) brought together and transcribed for the first time into Spanish and into a fully handwritten medium. If there were no khipu board accounts of each functionary's respective obligations in the champeria, and this was administered from memory prior to 1921, we can appreciate why mistakes or modifications by the functionaries would have highlighted the need for a constitutional agreement setting out the obligations in line with Inca law.

xi The word 'ciudadanos' (citizens) has been crossed out in red pen, and 'comuneros' has been written above in the same red pen, indicating tensions relating to identity in the context of nation-building. For the topic of nation-building in early twentieth century Peru, see Contreras and Oliart 2014, Durston 2018, Larson 2004, and Salomon and Niño-Murcia 2011.

xii The atypical spelling in the Spanish which can be observed here is characteristic of the non-standard spelling throughout the manuscript.

xiii Salomon glosses the Quechua term 'camachico' as 'president of an ayllu' (Salomon 2004:295), i.e. a president of a kin group. The Camachico is a key authority throughout the champeria in Casta, overseeing the 
submission of many of the obligatory offerings instructed in The Entablo and in the ritual khipu-board padrón accounts.

xiv Hornberger and Hornberger gloss 'waqay': "Cry, Say (certain animals), Sing (certain birds)" (Hornberger and Hornberger 2008:131).

${ }^{x v}$ My translation from the Spanish: 'Invocación que en los tiempos del Inkario se dirigía a los dioses implorando lluvia' (Lara 1971:312)

${ }^{\text {xvi }}$ My translation from the Spanish: 'Procesión nocturna que se realizaba por las calles pidiendo lluvia a los dioses en tiempo de sequía' (Lara 1971:312)

xvii According to Taylor, Jaqaru was the native tongue of the narrator of the Huarochiri manuscript of 1608. Linguistic analysis of the text by Taylor suggests that the information transcribed in the manuscript in the Quechua 'lengua general' was probably originally collected in Jaqaru and local varieties of Quechua, given that the narrator's own Jaqaru substrate emerges throughout the text (Taylor 2008:11-17).

xviii Poma's description of the ritual in Spanish reads: "Carnero negro ayuda a llorar y a pidir agua a dios con la hambre que tiene. /procición que piden agua a dios Runa Camag” (Poma 1615: 254 [256])

xix Poma wrote: "tenía muy entablado esta ley de la ydúlatras y serimonias de los demonios en este rreyno" ["he had this law about the idolatries and ceremonial worship of the devils set down in legal records throughout this kingdom"] (Poma 1615: 183 [185]).

${ }^{x x i}$ I am indebted to Christopher Heaney for alerting me to this research, and in particular to this linguistic note. xxii As Drinot has pointed out, within the context of early twentieth century nation-building in Peru, "Indians were governmentalised in order to reduce or eliminate the obstacle that they represented to the industrial nation" (Drinot 2011:14).

xxiii "Diglossia is a characterization of the societal allocation of functions to different languages or varieties" (Fishman 1972:145).

xxiv The hierarchy in language function in texts from Huarochirí is clear in the work of Salomon and NiñoMurcia, which notes that as yet, research on community archives [of Tupicocha and neighbouring districts] has not yielded community records in either Quechua or Jaqaru (Salomon and Niño-Murcia, 2011:22), suggesting that Quechua and Spanish maintained alternating functions through time. 
xxv “Después de la derrota y al cabo de algún (según los centenaries) Socta Curi regresó más o menos a los catorce años y al notar la miseria de los que habían sido sus súbditos se apenó muchísimo y les otorgó algunos beneficios entre ellos un abundante lluvia que hizo reverdecer las devastadas cementeras, víctimas de la rapiña de Huambo. A así de tiempo en tiempo ha venido haciendo sus periodicas visitas por el mes de enero, que los naturales conocen por su poderoso voz que difiere mucho de la lúgubre voz de Huambo. Estas visitas traen como consecuencia las copiosas lluvias que redundan en abundantes cosechas que benefician al pobladores de Casta" (Tello, undated papers: Textos originales-Cuaderno 30. Translation from the Spanish my own). I am grateful to Sabine Hyland who generously gave me permission to use her unpublished notes on the archive of Julio C. Tello.

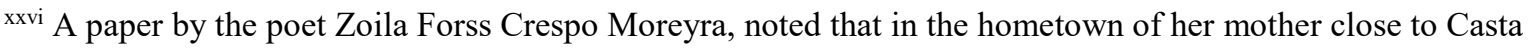
(Collata), Huambo hill is known to have sounds emanating from it (Zoila Forss Morayra, poetry reading at the Centre for Amerindian, Latin American and Caribbean Studies, University of St. Andrews, 24 April 2018). xxvii Hualinas are water songs performed during the champeria in Casta and neighbouring villages in the Santa Eulalia river valley.

xxviii It is not clear specifically who among the functionaries will make the announcement, but the Alcalde Campo functionary is responsible for shouting out during the January traditions, as will be explained below. xxix This section, in Spanish, reads: “Una vez terminado este partirán su marcha al lugar de 'Otagaca' y de ahí dará la voz con un 'Huajay’ que alertará a los expectadores y luego los funcionarios en unión de los aficionados suspenderán la hualina y procederán a poner el órden una vez que se encuentran ya expeditos se pondran de rodillas y daran reso varias oraciones para que le lleven con bién y encomendándose con todo corazón la fe que acaban de rezar para con Dios" (CCSPC 1921: f.8).

${ }^{\mathrm{xxx}}$ The work of Mannheim is an important precedent regarding the ontological implications of Quechua words and their untranslatability (Mannheim 2015).

xxxi The ritual significance of the site of Mashka is made clear in The Entablo's instructions for the Sunday evening, in preparation for the soon-to-commence champería. During the preparations, the Camachico is responsible for submitting three toritos (literally "little bulls"), one of which should be sacrificed at Machca [Mashka]. Village elder Eufronio Obispo Rojas explained that the idiosyncratic term 'toritos' mentioned in The Entablo refers to small guinea pigs used in rituals. Thus, guinea pig sacrifices are made at a site known to be a residence of Wallallo, who, as I mentioned earlier, is a huaca associated with blood sacrifice. 
xxxii This analysis of the functionary role fits with accounts of water rituals in Casta today, where a functionary is said to 'fire out' (tirar) a waqay.

xxxiii I am grateful to the anonymous reviewer whose etymological analysis of 'Wachiq' I have expanded on here.

${ }^{\text {xxiv }}$ A scholar of the Culle language who reported this Quechua toponym noted that she was unable to translate it into Spanish (Cuba 2014: 191).

xxxv "'Sonccoman huachik padremcaysoncco turpuk, sonccomanchayachik mana mattuchak. Este predicador hinca en el coraçon las palabras de Dios en el sermón como flechas”.

(Gonzales Holguín [1608] 1952:168).

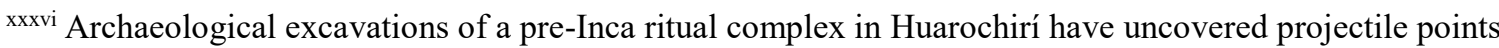
suggestive of ritual shooting in ancestor veneration (Hernández Garavito 2020: 11-12).

xxxvii The etymology of the Pre-Hispanic ritual complex of the Checa group located in San Damián, today known as 'Llaquistambo', is, according to the interlocutors of Salomon, linked to the idea of weeping (Salomon and Niño-Murcia 2011:308).

xxxviii During doctoral fieldwork in San Damián in 2012, elderly collaborators recalled the practice of insulting huacas during irrigation rituals they participated in during the mid-twentieth century. They explained that ritual functionaries wearing stilts would insult the huacas and enrage them.

${ }^{\text {xxxix }}$ An elderly collaborator in Casta mentioned to Bennison in 2018 that she had personally seen the stone of this 'queen' (la reyna).

${ }^{\mathrm{xl}}$ The work of Lund Skar describes how villagers in the jungle village of Chanchamayo walk to a site called 'Waqaipata', a "crying place" where people cry in order to draw their absent migrant family members back to the community (Lund Skar 1994:78). Thus, the act of crying at this site seeks to draw kin back to this time and place.

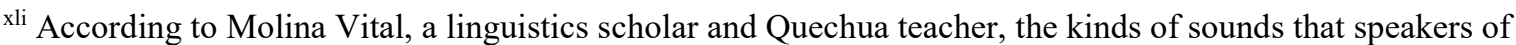
Quechua today convey using the verb waqay include rumbling, crying animals, and machines making noises (Carlos Molina Vital, personal communication).

xlii As I explained earlier, today in Casta, huacas are said to respond to cutting provocations delivered through 'strong words' such as swear words.

xliii The term yachaq can be glossed as 'Andean shaman' (Howard, Barbira-Freedman and Stobart 2002:18). 
xliv Another collaborator explained that the word 'pirwa' refers to crop production more generally. 


\section{References}

Adelaar, Willem F. H.

2017 Imperatives and Commands in Quechua. In Commands: A cross-linguistic typology, edited by Aîkhenval'd, A. I. U., \& Dixon, R. M. W.

Adelaar, Willem. and Pieter C. Muysken

2004 The Languages of the Andes (Cambridge Language Surveys). Cambridge: Cambridge University Press.

Arnold, Denise Y. with Juan de Dios Yapita

2006 The Metamorphosis of Heads: Textual struggles, education and land in the Andes. Pittsburgh: University of Pittsburgh Press.

Belleza Castro, Nelly

1995 Vocabulario jacaru-castellano castellano-jacaru (aimara tupino). Cusco, Perú: Centro de Estudios Regionales Andinos Bartolomé de las Casas.

Bennison, Sarah

2016 Who Are the Children of Pariacaca? Exploring identity through narratives of water and landscape in Huarochirí, Peru. Unpublished doctoral thesis, Newcastle University.

Bray, Tamara

2015 Introduction: Andean Wak'as and Alternative Configurations of Persons, Power \& Things. In The Archaeology of Wak'as: Explorations of the sacred in the Pre-

Columbian Andes, edited by Tamara Bray, 3-19. Boulder: University Press of Colorado. 
Burger, Richard

2009 The Life and Writings of Julio C. Tello. Iowa City: University of Iowa Press.

CCSPC (Comunidad Campesina de San Pedro de Casta)

1921 Entablo Comunal. Lima: Comunidad Campesina de San Pedro de Casta.

Contreras, Carlos and Patricia Oliart

2014 Modernidad y Educación en el Perú.

http://repositorio.cultura.gob.pe/handle/CULTURA/31. Lima: Ministerio de Cultura.

Course, Magnus

2018 Words beyond Meaning in Mapuche Language Ideology. Language \& Communication 63: 9-14

CSSD, Centro Social San Damián

1957 La Voz de San Damián, No. 1. Lima.

Cuba, María del Carmen.

2014. Catequilla y otros adoratorios de Cabana (Ancash-Perú): "Supervivencia de la cultura y lengua culle. III Encuentro de Lenguas Indígenas Americanas. Río Negro: Editorial UNRN 185-196.

Drinot, Paulo

2011 The Allure of Labor: Workers, race, and the making of the Peruvian state. Durham and London: Duke University Press.

Durston, Alan 
2018 Quechua-Language Government Propaganda in 1920s Peru. In Indigenous Languages, Politics, and Authority in Latin America: Historical and ethnographic perspectives, edited by Alan Durston and Bruce Mannheim. Indiana: University of Notre Dame Press.

Fishman, Joshua A.

1972 Language in Sociocultural Change. Stanford, Calif.: Stanford University Press.

García, Ofelia and Harold F. Schiffman

2006 Fishmanian Sociologistics 1949 to the present. In Language Loyalty, Continuity and Change: Joshua A. Fishman's contributions to international sociolinguistics, edited by Ofelia García, Rakhmiel Peltz, and Harold F. Schiffman, 1st ed., 3-68. Clevedon: Multilingual Matters.

Gelles, Paul H.

1984 Gelles, Paul H. 'Agua, faenas y organización comunal: San Pedro de Casta Huarochirí. Anthropologica Del Departamento De Ciencias Sociales, 2(2), 305-334.. Lima: Pontificia Universidad Católica del Perú

Gonzales Holguín, Diego

[1608] 1952 Vocabulario de la lengua general de todo el Peru llamada lengua Qquichua o del Inca. Lima: Universidad Nacional mayor de San Marcos, Instituto de Historia.

Gose, Peter 
1994 Deathly Waters and Hungry Mountains: Agrarian ritual and class formation in an Andean town. University of Toronto Press.

\section{Hall, Ingrid}

2014, December. Compter les journées de travail, classer les individus et ordonner la société dans une communauté des Andes sud-péruviennes. ethnographiques.org, no. 29 Ethnologie et mathématiques [http://www.ethnographiques.org/2014/Hall].

Hardman, Martha J.

1966 Jaqaru: Outline of phonological and morphological structure. The Hague: Mouton.

Hernández Garavito, Carla.

2020 Producing Legibility through Ritual: The Inka Expansion in Huarochirí (Lima, Peru). Journal of Social Archaeology 0, no. 0: 1469605320920127. https://journals.sagepub.com/doi/abs/10.1177/1469605320920127.

Hornberger, Esteban and Nancy Hornberger

2008 Diccionario trilingüe quechua de Cusco: qhiswa, English, castellano. Centro Bartolomé de las Casas.

Howard, Rosaleen

2012 Shifting Voices, Shifting Worlds: Evidentiality, epistemic modality and speaker perspective in Quechua oral narrative. Pragmatics and Society 3, no. 2: 243-269.

Howard, Rosaleen, Francoise Barbira-Freedman, and Henry Stobart

2002 Introduction. In Knowledge and Learning in the Andes. Ethnographic Perspectives. Liverpool Latin American Studies, edited by Henry Stobart and Rosaleen Howard, 113. New Series 3, Liverpool: Liverpool University Press. 
Hyland, Sabine

2016 How Khipus Indicated Labour Contributions in an Andean Village: An explanation of colour banding, seriation and ethnocategories. Journal of Material Culture 21, no. 4: 490-509. https://doi.org/10.1177/1359183516662677.

Hyland, Sabine

2011 Gods of the Andes: An Early Jesuit Account of Inca Religion and Andean Christianity. University Park: Pennsylvania State University Press.

Lara, Jesús

1971 Diccionario Qheshwa-Castellano Castellano-Qheshwa. La Paz and Cochabamba: Editorial "Los Amigos del Libro.”

Larson, Brooke

2004 Trials of Nation Making: Liberalism, race, and ethnicity in the Andes. Cambridge: Cambridge University Press.

Llanos, Oliverio and Jorge P. Osterling

1982 Ritual de la fiesta del agua en San Pero de Casta, Perú. Journal of Latin American Lore 8, no. 1: 115-150.

Mannheim, Bruce

2015 All Translation is Radical Translation. In Translating Worlds: The epistemological space of translation, edited by Carlo Severi \& William F. Hanks, 199-219. University of Chicago Press.

Mannheim, Bruce and Guillermo Salas Carreño 
2015 Wak'as: Entifications of the Andean sacred. In The Archaeology of W'akas:

Explorations of the sacred in the Pre-Columbian Andes, edited by Tamara Bray, 46-

72. University Presses of Colorado.

Mannheim, Bruce

1986 The Language of Reciprocity in Southern Peruvian Quechua. Anthropological Linguistics 28, no. 3: 267-273.

1991 The Language of the Inka since the European Invasion. Austin: University of Texas Press.

Nuckolls, Janis B.

2010 Lessons from a Quechua Strong Woman: Ideophony, dialogue, and perspective. Tucson: University of Arizona Press.

Ortiz Rescaniere, Alejandro

1980 Huarochirí, 400 años después. Lima: Pontificia Universidad Católica del Perú.

Osterling, Jorge P. and Oliviero Llanos

1982 Ritual de la fiesta del agua en San Pero de Casta, Perú. Journal of Latin American Lore 8, no. 1: 115-150

Padilla Deza, Fernando

2018 El concepto y la representación de lo indio en la propuesta política de Julio César Tello Rojas (1917-1929). Tesis de maestría en Historia. Lima: Pontificia Universidad Católica del Perú

Poma, Guaman

1615 Nueva corónica y buen gobierno (c. 1615) Royal Danish Library, GKS 2232. 
Platt, Tristan

1997 The Sound of Light: Emergent communication through Quechua shamanic dialogue. In Creating Context in Andean Cultures, edited by R. Howard-Malverde, 1st ed., 196-227. New York: Oxford University Press.

Ráez Retamozo, Manuel

1995 La Fiesta del Agua. Lima: Pontificia Universidad Católica del Perú, Instituto de Etnomusicología. Video directed by Manuel Raéz Retamozo.

Rivera Andía, Juan Javier

2005 Territorio e identidad en los Andes. Concepciones populares en torno a las zonas ecológicas altas en la sierra de Lima. Revista de Dialectología y Tradiciones Populares 60, no. 2: 55-76.

Salas Carreño, Guillermo

2018 On Quechua Relatedness to Contemporary and Ancient Dead. In Non-Humans in Amerindian South America: Ethnographies of Indigenous cosmologies, rituals and songs, edited by Juan Javier Rivera, 197-223. New York; Oxford: Berghahn Books.

Salomon, Frank

1998 Collquiri's Dam: The colonial re-voicing of an appeal to the Archai. In Native Traditions in the Postconquest World, edited by E. Hill Boone and T. Cummins, 1st ed., 265-293. Washington, D.C.: Dumbarton Oaks.

2002 “Huayra huayra pichcamanta!”: Augurio, risa y regeneración en la política tradicional (Pacota, Huarochirí). Bulletin de l'Institut français d'études andines 31, no. 1: 1-22. 
2004 The Cord Keepers: Khipus and cultural life in a Peruvian village. Durham: Duke University Press.

2019 The Long Afterlives of Central-Peruvian Khipu Patrimonies. Conference paper, symposium: Khipus: Writing Histories In and From Knots. The Mr. and Mrs. Raymond J. Horowitz Book Prize Symposium. 1 February 2019.

Salomon, Frank and Mercedes Niño-Murcia

2011 The Lettered Mountain: A Peruvian village's way with writing. Duke University Press.

Salomon, Frank

1991 'Introductory Essay: The Huarochirí Manuscript'. In The Huarochirí Manuscript: A testament of ancient and colonial Andean religion, translated from the Quechua by Frank Salomon and George L. Urioste. Austin: University of Texas Press, 1-38.

Salomon, Frank and George L. Urioste

1991 The Huarochirí Manuscript: A testament of ancient and colonial Andean religion, translated from the Quechua by Frank Salomon and George L. Urioste. Austin: University of Texas Press.

Skar, Sarah Lund

1994 Lives Together, Worlds Apart: Quechua colonization in jungle and city. Oslo: Scandinavian University Press, distribution worldwide by Oxford University Press.. 
Stobart, Henry

2001 La flauta de la llama: Malentendidos musicales en los Andes. In Identidades representadas: Performance, experiencia y memoria en los Andes, edited by G.

Cánepa Koch, 93-113. Fondo Editorial de la Pontificia Universidad Católica del Perú, Lima, Peru.

2006 Music and the Poetics of Production in the Bolivian Andes. Aldershot: Ashgate.

Taylor, Gerald

1974 Camay, Camac et Camasca dans le manuscrit quechua de Huarochiri. Journal de la Société des Américanistes. Tome 63: 231-244.

Taylor, G. and F. Avila

2008 Ritos y tradiciones de Huarochirí. Lima: Instituto Francés de Estudios Andinos.

Tello, Julio C.

1922 Los mitos de Casta, transcribed by Sabine Hyland. Textos originales, cuaderno 30. Archivo Tello, La Casona de la Universidad de San Marcos.

Tello, Julio C., and Próspero Miranda

1923 Wallallo: Ceremonias gentilicas realizadas en la region cisandina del Peru Central. Revista Inca 1, no. 2: 475-549.

Urton, Gary

2017 Inka History in Knots: Reading Khipus as Primary Sources. Austin: University of Texas Press. 
Vaughan, Jill and Ruth Singer

2018 Indigenous Multilingualisms Past and Present. Language \& Communication 62.

Valderrama Fernández, Ricardo and Carmen Escalante Gutierrez

1996 Andean Lives: Gregorio Condori Mamani and Asunta Quispe Huamán. Paul

Gelles, and Gabriela Martínez Escobar, eds. and trans. Austin: University of Texas

Press. 